\title{
Hydrologic and landscape changes in the Middle Ebro River (NE Spain): implications for restoration and management
}

\author{
A. Cabezas ${ }^{1}$, F. A. Comín ${ }^{1}$, S. Beguería ${ }^{2}$, and M. Trabucchi ${ }^{1}$ \\ ${ }^{1}$ Pyrenean Institute of Ecology, IPE-CSIC, Zaragoza, Spain \\ ${ }^{2}$ Aula Dei Experimental Station, EEAD-CSIC, Zaragoza, Spain
}

Received: 20 August 2008 - Published in Hydrol. Earth Syst. Sci. Discuss.: 30 September 2008

Revised: 5 January 2009 - Accepted: 20 January 2009 - Published: 25 February 2009

\begin{abstract}
The changes of landscape (1927-2003), discharge regime and anthropic activities with the river-floodplain of one reach at the Middle Ebro River (NE Spain) were investigated with the objective to identify the factors that best explain the natural ecotope succession and propose a realistic restoration option with consideration of the landscape dynamics during the last century and the socio-economic context. Our results indicate that hydrological and landscape patterns have been dramatically changed during the last century as a consequence of human alteration of the fluvial dynamics within the studied reach. The magnitude and variability of river discharge events have decreased at the end of the last century, and flood protection structures have disrupted the river floodplain connectivity. As a result, the succesional pathways of riparian ecotopes have been heavily modified because natural rejuvenation no longer takes place, resulting in decreased landscape diversity. It is apparent from these data that floodplain restoration must be incorporated as a significant factor into river management plans if a more natural functioning wants to be retrieved. The ecotope structure and dynamics of the 1927-1957 period should be adopted as the guiding image, whereas current hydrologic and landscape (dykes, raised surfaces) patterns should be considered. Under the current socio-economic context, the more realistic option seems to create a dynamic river corridor reallocating dykes and lowering floodplain heights. The extent of this river corridor should adapt to the restored flow regime, although periodic economic investments could be an option if the desired self-sustained dynamism is not reached.
\end{abstract}

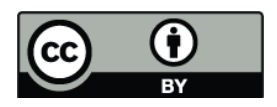

Correspondence to: A. Cabezas (acabezas@ipe.csic.es)

\section{Introduction}

Linking landscape patterns and ecological processes is a common goal of landscape ecology (Forman and Godron, 1986). Landscape ecology holds the potential for developing a truly holistic perspective of river corridors by integrating structure, dynamics and function (Ward et al., 2002). The diversity of landscape units and their spatial distributions in pristine riverine landscapes are the result of geomorphological and biological processes and interactions operating across a wide range of spatio-temporal scales. As a consequence, it was through the interpretation of sequential landscape patterns that the primary drivers of the riverine landscape dynamics have been inferred in different studies (Miller et al., 1995; Hohensinner et al., 2004; Geerling et al., 2006; Whited et al., 2007). A full range of phenomena, ranging from catastrophic events to predictable mean flow, generate the fluvial dynamics and fluctuating hydrological connectivity that characterizes intact river-floodplain systems (Jungwirth et al., 2002). Riparian succession tends to drive aquatic environments toward terrestrial landscapes, but erosion and deposition during low-frequency floods truncate those successional pathways. As a result, in a diverse landscape which contains landscape units at every stage of succession, irregular and anticipated, events drive hydrogeomorphological functions and, in general, allow the system to remain stable (Amoros and Wade, 1996).

Anthropogenic alterations of floodplains often disrupt the intensity, frequency and timing of the natural disturbance regime that is key to the ecological integrity of riverine environments (Ward and Stanford, 1995). The need and/or desire for new space to develop, occupy and/or farm has greatly disturbed floodplains of small and large rivers alike. As a consequence, floodplains are among the most threatened ecosystems in the world despite their biological importance

Published by Copernicus Publications on behalf of the European Geosciences Union. 
(Tockner and Stanford, 2002). At the Ebro River, in northeast Spain, the promotion of dam construction for irrigation purposes during the last century (Pinilla, 2006), resulted in the accelerated occupation of river margins and massive construction of flood protection structures. In the middle stretch of the Ebro, only about $4 \%$ of the floodplain is covered by natural vegetation (Ollero, 1992). Regato (1988) reported that natural vegetation had been strongly modified within the Ebro River study reach by alteration of the fluvial dynamics; this was later confirmed by Castro et al. (2001). Floodplain habitats, therefore, must be a critical component of river management for the Water Framework Directive to be successfully applied on the Ebro River.

To achieve the restoration of threatened river systems, a complete understanding of geomorphological and ecological processes is required (Kondolf, 1998). Such an understanding will serve as a basis to predict the potential effects of performing site-specific restoration either alone or in combination with flow allocation on a basin-wide scale. In this paper, the landscape dynamics of one study reach in the Middle Ebro River are investigated, as well as changes in the natural flow regime and anthropic activities, in order to achieve the next tasks: (a) examine changes in hydrological and landscape patterns (b) identify the factors that best explain the natural ecotope succession and (c) propose a realistic restoration option with consideration of the landscape dynamics during the last century and the socio-economic context.

\section{Methods}

\subsection{Study area}

The study reach was located in the Middle Ebro River, NE Spain (Fig. 1). This is the largest river in Spain (watershed area $=85362 \mathrm{~km}^{2}$, river length $=910 \mathrm{~km}$, average annual discharge to the Mediterranean Sea $=14442 \mathrm{Hm}^{3}$; 1927-2003) and is still geomorphologically active. Within this section, the average floodplain width is about $5 \mathrm{~km}$. The main channel has a wandering morphology (sinuosity $=1.39$, mean channel slope $=0.050 \%$, mean channel width $=110.31 \pm 36.3 \mathrm{~m}$ ), with elongated meanders and scarcity of in-channel islands. Within the study reach, the daily average discharge is $227.48 \mathrm{~m}^{3} / \mathrm{s}(1927-2003)$ and the elevation ranges between $175 \mathrm{~m}$ a.s.l. in the river channel to $185 \mathrm{~m}$ a.s.l. at the base of the scarp. The estimated area that would be inundated by the 10 -y flood event $\left(3000 \mathrm{~m}^{3} / \mathrm{s}\right.$, $1927-2003$ ) is $2230 \mathrm{ha}$, although only about $14 \%$ of that area would be inundated during a $1000 \mathrm{~m}^{3} / \mathrm{s}$ flood event (0.37 years return period, 1927-2003), and only 4\% would be flooded by a river discharge of $500 \mathrm{~m}^{3} / \mathrm{s}$. Upstream of the city of Zaragoza, the catchment area is $40434 \mathrm{~km}^{2}$ and the dam-equivalent capacity is $1637.19 \mathrm{Hm}^{3}$. The flow regime has changed along the last century at the study reach, as reflected by the annual average discharge (Fig. 2).

\subsection{Hydrological analysis}

Due to its main role in river-floodplain systems (Junk et al., 1989; Tockner et al., 2000), the pulsing of the river discharge, i.e. flood pulse, was used to characterize the hydrological patterns. It served as a basis to interpret landscape changes, although further analyses are required to interpret the direct effect of the components of the flow regime (magnitude, frequency, duration, timing, rate of change) over ecotope dynamics (see Poff et al., 1997). Daily average discharge, from 1927 to 2003 at Zaragoza city gauging station (A011), was provided by the Ebro River Basin Administration (www.chebro.es). This gauging station is located $12 \mathrm{~km}$ upstream of the study area and there are no major water diversions between the station and the study area; the discharge values, therefore, should be representative of conditions within the study area. River discharge is inferred from water level measures using trough a rating curve. Water level is measured using shaft encoder meter (OTT®), being $8 \mathrm{~m}$ the maximum measureable height. Every month, direct discharge measures are performed using a river surveyor (RIVERCAT $\left.{ }^{\circledR}\right)$ to calculate a rating curve $(n=300)$, which is modified if level and discharge do not fit conveniently. The rating curve is built by fitting linear regressions between nearby points. Maximum discharge value used in the rating curve is $2000 \mathrm{~m}^{3} / \mathrm{s}$, and the confidence level is about 5\% (CHE, personal communication). A times series of flood events was generated from the original daily average discharge. A flood event was defined as a series of one or more consecutive days with average daily discharge equal or higher than $600 \mathrm{~m}^{3} / \mathrm{s}$. For each flood event the duration and peak discharge were recorded. A magnitude-frequency analysis of flood events was conducted using the partial duration series approach, with the purpose of determining the recurrence time of characteristic flood events. The partial duration series approach was preferred over the annual maximum series, which is the most widespread technique, due its superior mathematical properties and robustness (Beguería, 2005). The series of flood events were fitted to a Generalised Pareto distribution, which is the limit distribution for a series of events over a fixed threshold (Cunnane, 1973). In order to interpret ecotope dynamics through the hydrological patterns, data were separated and analyzed for three different periods (1927-1957; 1957-1981; 1981-2003), which coincide with the time-spans between aerial pictures and represent changes in hydrology during the study period (Fig. 2). Further research is necessary to evaluate the importance of the last-flood effect on landscape dynamic at each year, although we assume for this paper that landscape patterns are the result of the hydrological patterns along an extended period rather than individual floods. Bankfull discharge, an important parameter controlling channel and floodplain morphology, was defined as the flood event with an estimated recurrence time of $1.58 \mathrm{y}$ (see Dury, 1981). Similarly, recurrence times for other river discharge values were also estimated for further 


\begin{tabular}{|c|c|c|c|}
\hline \multicolumn{4}{|c|}{ Land-Cover Types } \\
\hline & MAIN CHANNEL & & INTERMEDIATE ISLAND \\
\hline & GRAVEL & $m$ & SCATTERED TREES \\
\hline & FNES & & MATURE \\
\hline & OPEN WATER & & MATURE ISLAND \\
\hline & YOUNG ISLAND & MID & ANTHROPIC \\
\hline & INTERMEDIATE & & \\
\hline 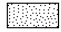 & BURIED TREES & & \\
\hline & MACROPHYTES & & \\
\hline EIIA & HERBACEOUS & & \\
\hline
\end{tabular}
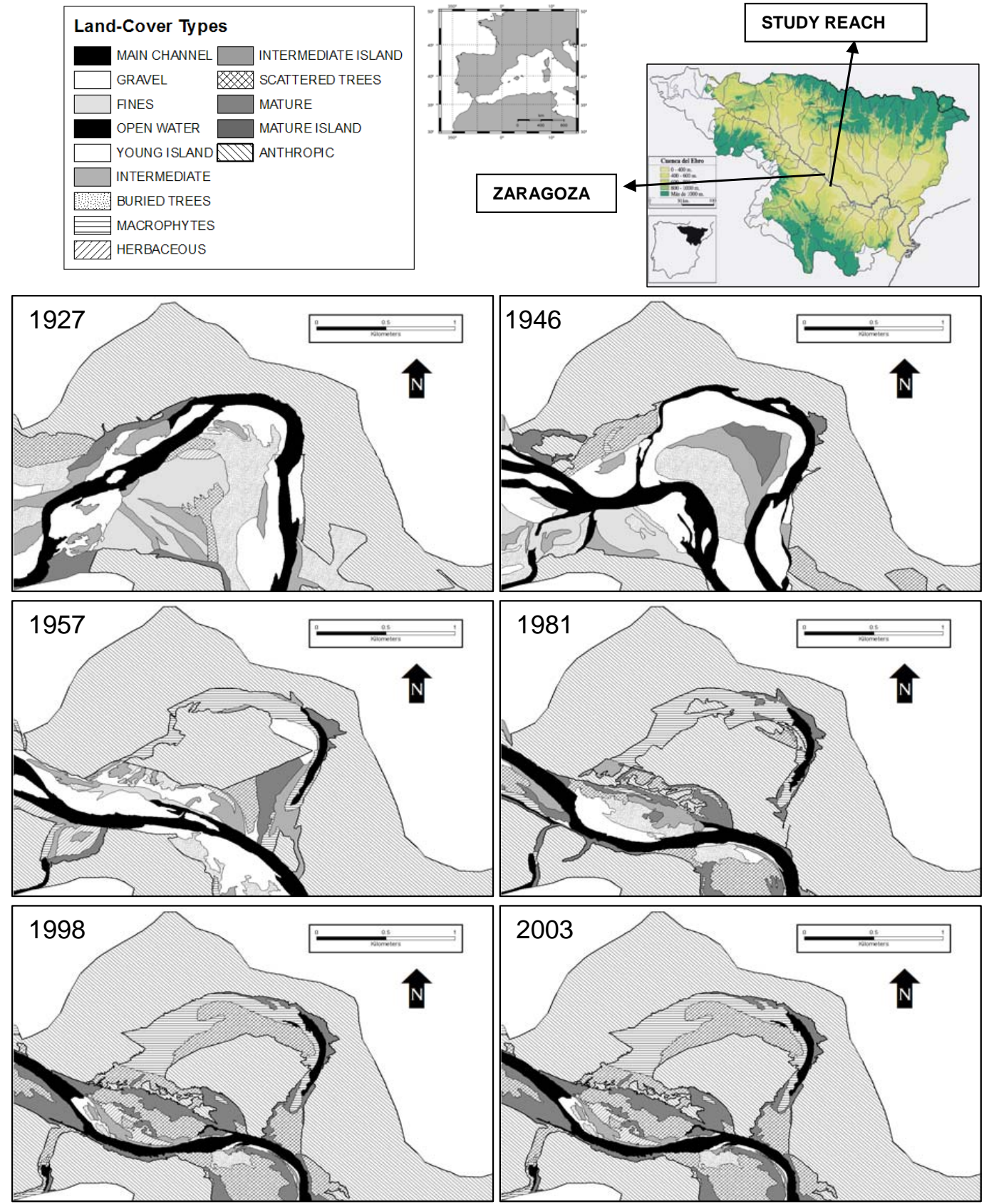

Fig. 1. Ecotope maps for a representative part of the study reach, including each of the six years considered in the study. River flow is from the upper left to lower right. There has been essentially no main channel migration between 1981 and 2003. No significant changes were detected between 1998 and 2003.

inter-period comparisons. Finally, the mean annual discharge at the Zaragoza gauging station was also calculated.

\subsection{Landscape analysis}

Ecotope maps (Fig. 1) were generated from a set of aerial photographs (1927, 1946, 1957, 1981, 1998 and 2003, all taken at low water levels) to perform a landscape transition analysis using GIS techniques. The 1946, 1957 and 1981 photographs were black-and-white at different resolution scales (1:40 000, 1:33000 and 1:18000, respectively). They were rectified and georeferenced using LPS ${ }^{\circledR} 9.1$ (ERDAS Imagine 9.1®). The 1927 images were supplied by the Ebro River Basin Administration as rectified aerial photographs (1:10000) and georeferencing was performed with ArcGis $9.2 ®$. Both maps and aerial pictures had been previously 
Table 1. Ecotope types used to define landscape units.

\begin{tabular}{lll}
\hline Ecotope & Successional Stage & Description \\
\hline Main Channel & - & Area occupied by main channel \\
Gravel & Initial & Covered by gravel, adjacent to the main channel \\
Fines & Initial & Covered by fine substrate, adjacent to the main channel \\
Open water & Initial & Flooded areas with no emergent vegetation \\
Young Island & Initial & Located in-shore, covered by gravels \\
Intermediate & Intermediate & Closed canopy $(>75 \%)$, young individuals \\
Buried trees & Intermediate & Coarse substrate, clustered young trees \\
Macrophytes & Intermediate & Covered by emergent vegetation \\
Herbaceous & Intermediate & Absence of trees, not adjacent to the main channel \\
Inter. Island & Intermediate & Located in shore, not covered by gravels or mature trees \\
Scattered Trees & Mature & Fine substrate, clustered mature trees. \\
Mature & Mature & Closed tree canopy $>75 \%)$, mature individuals \\
Mature Island & Mature & Located in shore, covered by mature trees \\
Anthropic & - & Agricultural fields or poplar groves \\
\hline
\end{tabular}

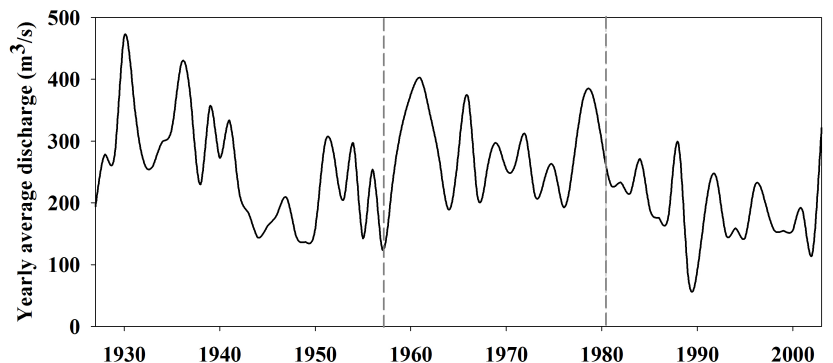

Fig. 2. Yearly average discharge for the study period (1927-2003) at the Zaragoza City gauging station. Dash lines indicate the periods when hydrological data was separated for the analysis of flood events.

scanned at $600 \mathrm{dpi}$, yielding raster images with a pixel resolution from 1 to $2 \mathrm{~m}$. Positional accuracy $(n=20)$ in the studied floodplain averaged $5 \mathrm{~m}$ for all georeferenced images. Finally, 1998 and 2003 aerial pictures were supplied by the Aragon Regional Government as georeferenced images with a 1.0 and $0.5 \mathrm{~m}$ pixel resolution, respectively.

Three years of field campaigns served as a basis for the identification of ecotope types (Table 1). Landscape units were delimited on the aerial pictures. This method is only applicable if pictures have been taken at comparable water levels. Landscape patches were digitized using ArcGis 9.2® with a fixed scale of 1:3000. At recent aerial pictures (19272003), the ecotope type was assigned to the different units directly on ecotope maps during field campaigns. Since all the study area was surveyed, any ground-truthing statistical test was performed. For the older aerial pictures (1927, 1946, 1957, 1981), landscape units were classified following a simple interpretation-key made from the observed relationships between field ecotopes and map units in the former photos. The key was created using texture, colour, tree density, ver- tical structure, position in the landscape or previous channel migration dynamics. When possible, a stereoscope was used to exploit the original quality and vertical information of the aerial photos. All patches smaller than $64 \mathrm{~m}^{2}$ were eliminated and vector maps were rasterised to a $10 \times 10 \mathrm{~m}$ grid using ArcGis 9.2®.

To explore the relationship between landscape structure and river-floodplain interactions, ecotope maps were progressively truncated by increasing the distance to the main channel (considering the thalweg of each year) by $100 \mathrm{~m}$, up to $1000 \mathrm{~m}$, and every $500 \mathrm{~m}$ from 1000 to $2500 \mathrm{~m}$. This $2500 \mathrm{~m}$ buffer comprises the $10 \mathrm{y}$ floodplain, which has been considered the reference area for the landscape metrics. Delineation of this reference area was defined by the Ebro River Basin Administration using remote sensing data and groundtruthing during the February 2003 flood, which peaked at $2988 \mathrm{~m}^{3} / \mathrm{s}$ at the Zaragoza gauging station (Losada et al., 2004). For all buffers considered in this study, Fragstats 3.3 (McGarigal and Marks, 1995) was used to calculate the area and percentage of land occupied by each ecotope category, as well as ecotope diversity using the Shannon Index. The Shannon Index $(H)$ is commonly used to measure biological diversity in categorical data. This index considers the number of species the evenness of each specie, calculated as follows $H=-\sum p_{i}^{*} \ln p_{i}$ ( $p_{i}$ : ecotope proportion of type $i$ ). It has been widely applied in landscape studies (McGarigal and Marks, 1995). Cumulative diversity spectra, considering buffers progressively further from the main channel, were plotted. The shape of the spectra is expected to indicate spatial distribution of ecotope diversity, and so the effect of a more active fluvial dynamic or anthropic occupation of the outer floodplain. On the other hand, diversity at the $2500 \mathrm{~m}$ buffer indicates the total landscape diversity.

To examine ecotope change, transition matrices and maps were produced for each time span using IDRISI 


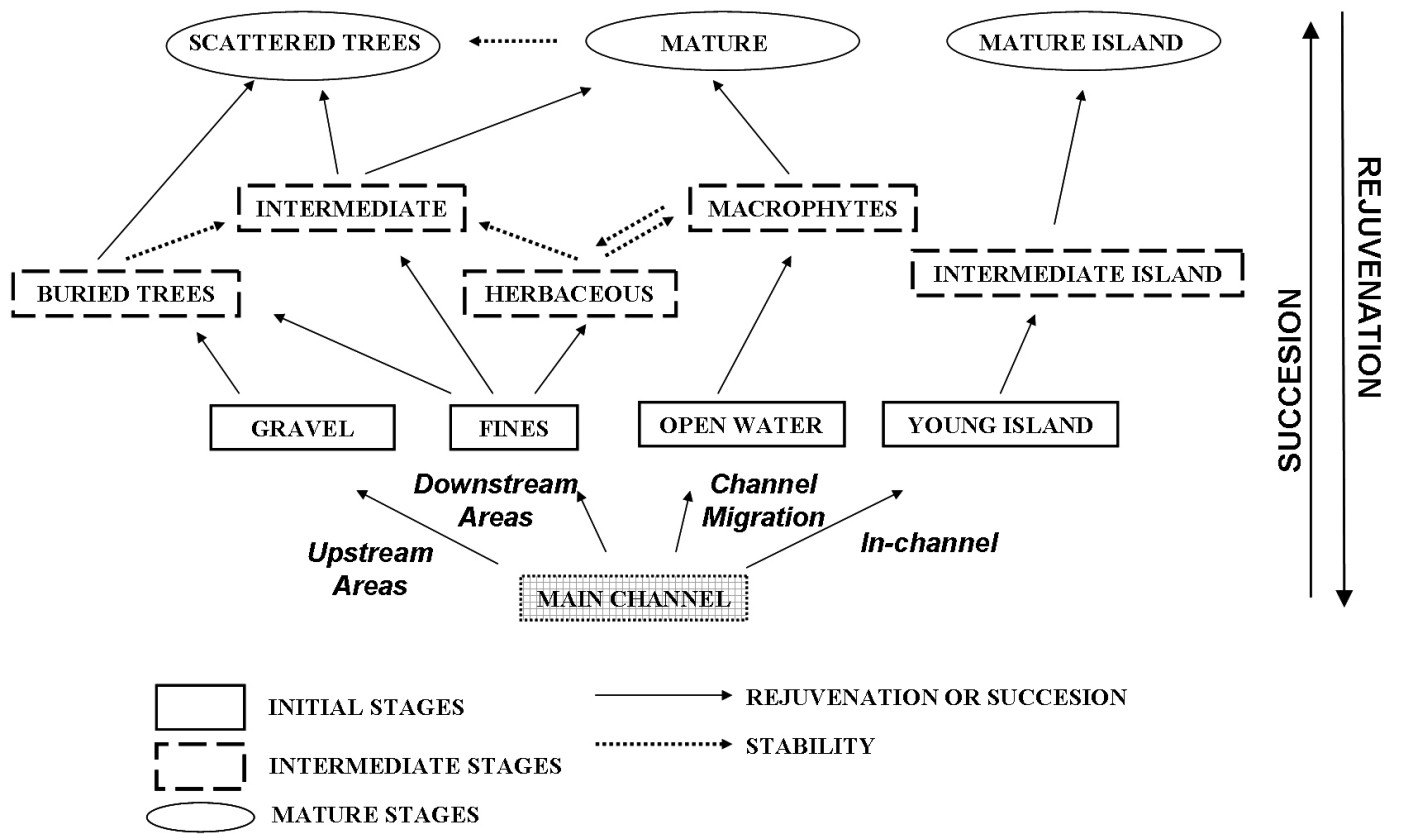

Fig. 3. Ecotope succession scheme. See explanations in the text (Methods section).

Kilimanjaro® (CrossTab). A general ecotope succession model (Fig. 3) was then created from the interpretation of transition matrices and previous research on vegetation dynamics (Braun Blanquet and de Bolós, 1987; Regato, 1988). In this scheme (Fig. 3) arrows between natural ecotopes (all ecotopes less "anthropic") indicate the linear trend towards more mature ecotopes of riparian succession. Every ecotope transition was classified either as Natural transitions or as Human-affected transition. Natural transitions are those between natural ecotopes (e.g. "main channel" towards "gravel"), which were classified as succession (SUC), rejuvenation (REJ) or stability (STA) according to the succession model: transitions between ecotopes at the same stage (initial, intermediate or mature in Fig. 3) were considered as STA; those transitions between ecotopes at different stage were considered as SUC or REJ depending on the direction (Fig. 3), also reflecting the possibility of direct transitions by any ecotope at mature and initial stages. Finally, humanaffected transitions were those from a natural ecotopes towards the "anthropic" ecotope type. Using the cartographic ecotope data from the previous year, we determined how ecotope types developed from the initial patchwork. For this analysis, the importance (\%) of SUC, REJ and STA (Natural transitions) during the analysed snap-shots was represented in triangular ternary plots as recently constructed by Geerling et al. (2006). Human-affected transitions were consequently discarded for this analysis. For an easier interpretation of the results, the transitions were later grouped into the three time periods in accordance with the hydrological analysis: (a) 1927-1957, transitions 1 and 2, (b) 1957-1981, transition 3 and (c) 1981-2003, transitions 4 and 5.

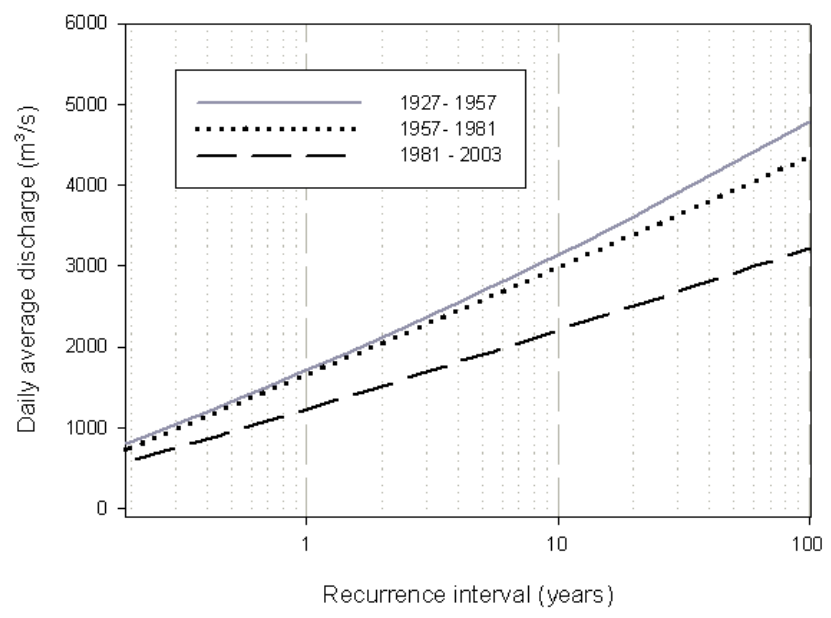

Fig. 4. Magnitude-frequency plots illustrating reduced frequency of high-discharge events in more recent years.

\section{Results}

\subsection{Hydrological analysis}

Our analysis revealed a clear decrease in the mean annual discharge at the Zaragoza gauging station. Although discharge showed a slight increase in the first two periods (1927-57 and 1957-1981), rising from 7930 to $8720 \mathrm{Hm}^{3} / \mathrm{y}$, then felt to $5834 \mathrm{Hm}^{3} / y$ during the last twenty years. The frequency of floods also decreased for the last period considered (Fig. 4). Similar-magnitude discharges were estimated to occur with similar frequencies from 1927 to 1981, after which their 
Table 2. Number, frequency and duration of flood events at the Zaragoza gauging station. Data were analyzed separately for the three temporal periods. Flood events were considered if exceeds $600 \mathrm{~m}^{3} / \mathrm{s}$ and categorized according to the estimated bankfull discharge $\left(1927-1957=1980 \mathrm{~m}^{3} / \mathrm{s} ; 1957-1981=1957 \mathrm{~m}^{3} / \mathrm{s} ; 1981-\right.$ $\left.2003=1410 \mathrm{~m}^{3} / \mathrm{s}\right) . \mathrm{Q}_{p}=$ Flood magnitude.

\begin{tabular}{llllll}
\hline Period & $\mathrm{Q}_{p}\left(\mathrm{~m}^{3} / \mathrm{s}\right)$ & \multicolumn{2}{c}{ Events } & \multicolumn{2}{c}{ Duration $(\mathrm{d})$} \\
& & total & per year & total & per event \\
\hline $1927-1957$ & $600 \leq \mathrm{Q}_{p} \leq 1980$ & 206 & 7.1 & 811 & 3.94 \\
& $\mathrm{Q}_{p}>1980$ & 21 & 0.72 & 335 & 15.95 \\
$1957-1981$ & $600 \leq \mathrm{Q}_{p} \leq 1957$ & 146 & 5.84 & 669 & 4.58 \\
& $\mathrm{Q}_{p}>1957$ & 20 & 0.8 & 310 & 15.5 \\
$1981-2003$ & $600 \leq \mathrm{Q}_{p} \leq 1410$ & 90 & 4.09 & 303 & 3.37 \\
& $\mathrm{Q}_{p}>1410$ & 16 & 0.73 & 161 & 10.06 \\
\hline
\end{tabular}

periodicity declined. For example, a $3000 \mathrm{~m}^{3} / \mathrm{s}$ event, which served to delimit the floodplain area, had a recurrence time of $8 \mathrm{y}$ and $10 \mathrm{y}$ in the periods $1927-1957$ and 1957-1981, respectively. From 1981 and 2003, however, the frequency of an event of that magnitude decreased, with a recurrence time of 60 years. Similarly, the bankfull discharge dropped slightly from 1980 to $1917 \mathrm{~m}^{3} / \mathrm{s}$ between the first and the second time periods, but diminished substantially to $1410 \mathrm{~m}^{3} / \mathrm{s}$ in the 1981 to 2003 period. The number of flood events in which the peak exceeded the bankfull discharge has decreased since 1981 (Table 2) although no real drop was visible in the per year occurrence. Also the duration of these flood events were higher before 1981. With regards to the floods that peaked below bankfull discharge, the number and frequency have progressively dropped during the study period, going from 206 sub-peak events in the 1927-1957 period (7.10 events per year), to only 90 such events in the 1981-2003 period (4.09 events per year). However, duration of sub-peak events have oscillated, reaching a maximum ( $4.58 \mathrm{~d}$ per event) in the $1957-1981$ period, and a minimum ( $3.37 \mathrm{~d}$ per event) in the most recent period, showing no clear trends.

\subsection{Landscape analysis}

Ecotope maps show how drastically the landscape structure has changed from 1927 to 2003 (Fig. 1). Ecotope diversity has decreased over that same period. The Shannon Diversity index $(H)$ of the entire floodplain area, which corresponds to the $2500 \mathrm{~m}$ buffer, dropped from 1.78 in 1927 and 1946 to 1.08 in 1998 and 2003 (Fig. 5). In 1981, this index was slightly lower than in 1998. In addition, there has been a spatial change in ecotope diversity within the floodplain relative to proximity of the main river channel. Prior to 1981, ecotope diversity peaked at a distance of $200-300 \mathrm{~m}$ from the river bank and then decreased with increasing distance from the river; the 1946 spectra shows a secondary, though slight, peak at $900 \mathrm{~m}$. However, the 1981, 1998 and 2003

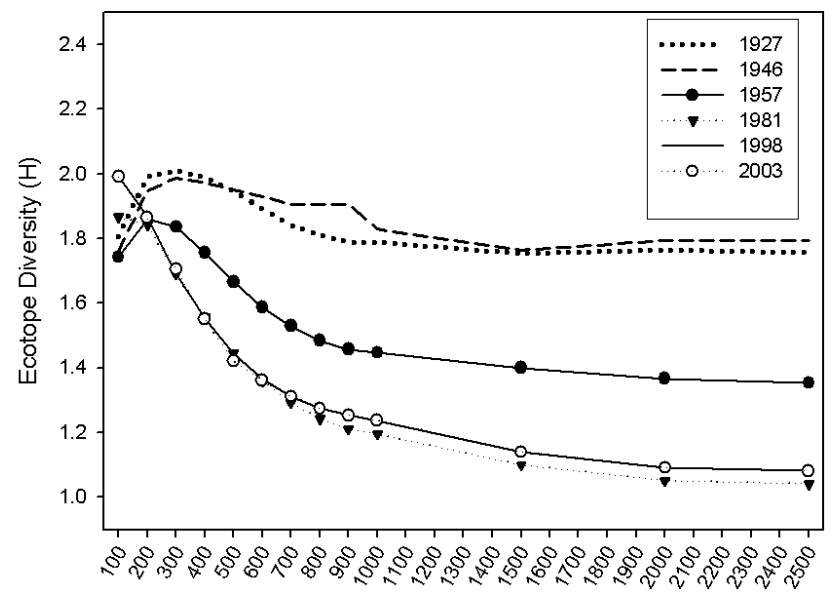

Distance to the river channel $(\mathrm{m})$

Fig. 5. Ecotope diversity as a function of distance to the river channel. Note that 1998 and 2003 plots are superimposed.

data show maximum ecotope diversity at just $100 \mathrm{~m}$ from the main channel, followed by a rapid and steep drop.

Elongated meanders were present in the 1927 maps, but these oxbow channels were cut-off before 1946 (Fig. 1). Lateral accretion caused the main channel to migrate between 1946 and 1981, and established its current location. The area of the main channel decreased over the study period ( $8.24 \%$ in 1927 to $5.33 \%$ in 2003, Table 3), whereas humanoccupation of the river space has markedly increased in importance, especially between 1946 and 1981. This change appears true not only for the outer margins of the floodplain, where incremental impacts would be expected and dominated by intermediate and mature ecotopes (Fig. 1), but also for the natural riparian corridor, adjacent to the main channel, which has narrowed considerably (Fig. 1). On the contrary, the percentage occupied by natural ecotopes has decreased from $49.5 \%$ to $26.4 \%$ during the study period (Table 3). Mature ecotopes maintain their importance despite such decreased, although it was lower between 1946 and 1981. On the other hand, the portion covered by initial and intermediate ecotopes drastically drop during the examined period.

Natural patches at different successional stages (Table 1) evolved in a distinctive manner during the examined transitions (Fig. 6). Between 1927 and 1957, either rejuvenation (REJ) or stability (STA) were in balance with succession (SUC) for initial ecotopes, which was even impeded for the "gravel" and "fines" patches in the 1927-1946 transition. For the intermediate stages, distinct successional pathways (Fig. 3) resulted in a different dynamics. "Intermediate" and "buried trees", normally located adjacent to the main channel, showed high REJ percentages. However, succession was balanced with stability during the same period for "macrophytes". No clear trends were detected for "herbaceous" 
and "intermediate island". Finally, about the $30 \%$ of the patches occupied either by "scattered trees" or "mature" were renewed progressively between 1927 and 1957, while STA dominated for the remainder patches. From 1957 to 1981, trends were similar to those in previous period for "open water" and "gravel", but SUC became dominant for "fines" and "young island". For intermediate stages, SUC also emerged as the dominant process, although REJ was also important. Referring to mature ecotopes, rejuvenation at areas adjacent to the main channel (around 50\%) and anthropization in the outer floodplain (Table 3) restricted the establishment of "scattered trees" and "mature". Finally, all ecotope types showed a slight trend towards STA between 1981 and 1998, with the exception of "island" ecotopes. During this period, REJ became nearly nonexistent (Fig. 6). Moreover, all ecotopes showed increasing signs of stability after 1998, despite the potential erosive effect of a $10 \mathrm{y}$ flood (1927-2003 data) in February 2003.

\section{Discussion}

\subsection{Changes in hydrological and landscape patterns}

Over the last century, the natural flow regime in the Middle Ebro River has been modified by progressive river flow regulation and anthropization of the catchment area. During the last part of the century, discharge magnitude and variability have markedly decreased (Figs. 2 and 4). According to our analysis, the mean annual discharge within the study reach has declined approximately $30 \%$ since 1981 , coinciding with the decrease of bankfull discharge. Various researchers have suggested that this phenomenon has been caused by the progressive increase of evapotranspiration due to higher temperatures, reforestation of abandoned agricultural fields in mountainous areas, increase in reservoir water storage (volume and surface area) and the expansion of irrigated farmlands (Ibañez et al., 1996; Ollero, 2007). In basin areas upstream of the study reach, a sharp increase in the total equivalent capacity of reservoirs occurred between 1950 and 1980, in parallel with the expansion of irrigated land. However, the emphasis on agricultural production since the 1980's was driven to a large degree by the cultivation of water-hungry crops such as rice, fruits or vegetables (Frutos et al., 2004). In addition to this increased demand, precipitation peaked during the 1970s in nearly all of the Ebro Basin (Abaurrea et al., 2002), which may have helped to dampen the effect of human impacts on the system. Flood events, flow and flood pulses (see Tockner et al., 2000) have shown distinct patterns of change in their frequency and duration (Table 2). Our analysis detected that events above the bankfull discharge decreased in duration but not in number since 1981, while those below bankfull discharge decreased only in number. The management of the largest reservoirs for irrigation purposes might explain those trends. In winter, the
Table 3. Area $(\%)$ covered by each ecotope in each year. Percentages are calculated for the total floodplain area $(2230 \mathrm{Ha})$. Subtotals by succesional stage (see Table 1) are also displayed.

\begin{tabular}{lrrrrrr}
\hline & 1927 & 1946 & 1957 & 1981 & 1998 & 2003 \\
\hline Main Channel & 8.2 & 9.1 & 6.8 & 6.6 & 5.3 & 5.3 \\
Gravel & 8.0 & 10.1 & 6.8 & 2.6 & 1.3 & 1.2 \\
Fines & 2.6 & 3.1 & 0.4 & 0.4 & 0.6 & 0.6 \\
Open Water & 0.5 & 1.6 & 0.8 & 1.0 & 0.7 & 0.7 \\
Young Island & 0.6 & 1.7 & 0.2 & 0.5 & 0.2 & 0.2 \\
\hline Initial & 20.0 & 25.5 & 15.0 & 11.1 & 8.0 & 8.0 \\
\hline Intermediate & 5.4 & 5.1 & 4.6 & 2.4 & 1.2 & 1.3 \\
Buried Trees & 6.2 & 3.0 & 2.7 & 1.2 & 0.3 & 0.4 \\
Macrophytes0 & 7.0 & 4.1 & 4.6 & 1.8 & 2.2 & 2.3 \\
Herbaceous & 0.1 & 0.1 & 0.7 & 0.2 & 0.5 & 0.5 \\
Inter. Island & 0.4 & 0.0 & 0.0 & 0.1 & 0.0 & 0.0 \\
\hline Intermediate & 19.1 & 12.3 & 12.6 & 5.7 & 4.3 & 4.4 \\
\hline Scattered Trees & 4.4 & 10.8 & 4.3 & 2.9 & 7.9 & 7.9 \\
Mature & 6.1 & 3.7 & 2.4 & 4.0 & 6.0 & 5.9 \\
Mature Island & 0.0 & 0.0 & 0.0 & 0.1 & 0.2 & 0.2 \\
\hline Mature & 10.5 & 14.5 & 6.7 & 6.9 & 14.1 & 14.0 \\
\hline Natural & 49.5 & 52.3 & 34.3 & 23.7 & 26.4 & 26.4 \\
Anthropic & 50.5 & 47.7 & 65.7 & 76.3 & 73.6 & 73.6 \\
Total & 100.0 & 100.0 & 100.0 & 100.0 & 100.0 & 100.0 \\
\hline
\end{tabular}

number of floods is dampened using the existing flood control infrastructure in order to store water for summer, when irrigation demand is high. Given the winter storage goals, the capacity of flood-control systems to mitigate large floods in early spring, when the snowmelt occurs, is minimal. This has been previously described for dams located in the Pyrenees, which are often at or near capacity at the onset of spring floods (Lopez-Moreno et al., 2002).

Landscape structure seemed to adapt to changes in the flow regime, although such adjustment was altered by human disruptions of river-floodplain interactions. Both human occupation of the river space and dyke construction have accelerated the evolution towards a less diverse landscape (Fig. 5). Natural ecotopes were replaced in the outer floodplain mainly by agricultural fields (Fig. 1), whereas natural areas close to the main channel became dominated by mature stages of riparian landforms (Table 3). The highest ecotope diversity (ED) was observed prior to the 1960s, when a peak of ED at 200-300 $\mathrm{m}$ from the main channel was also observed (Fig. 5). It seems that flood events maintained a diverse array of landforms in areas adjacent to the main channel. Beyond this area, the progressive dominance of "anthropic", intermediate and mature ecotopes forced a decline in diversity at that time. Prior to 1957 , large natural patches in the outer floodplain (Fig. 1) caused diversity to be similar in 1927 and, 20 years later, in 1946. However, agricultural expansion in the floodplain substantially lowered diversity only 10 years later in 1956. Conversion from natural 
A. Cabezas et al.: Landscape changes at the Ebro River
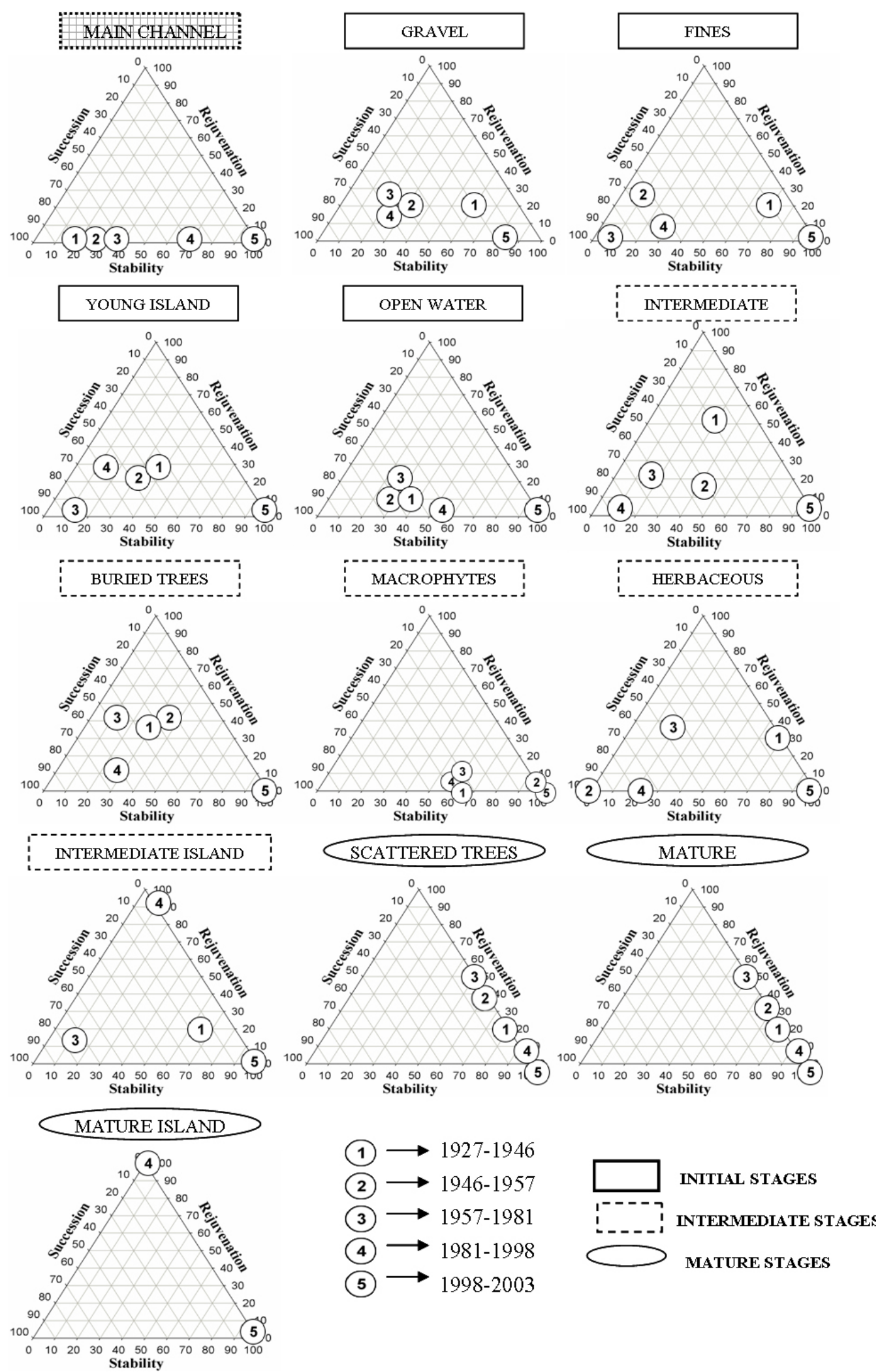

Fig. 6. Ternary plots for ecotope succession, rejuvenation or stability, considering the fraction of the ecotope not converted to "Anthropic". "Intermediate Island" did not exist in 1957 while "Mature Island" appeared in 1981. 
to anthropic ecotopes proceed almost entirely from 1946 to 1981, resulting in a two fold increase of the area covered by human managed ecotopes (Table 3). After abandonment, some of those human-manages patches have been covered by natural vegetation, what explains the slight increase of ecotope diversity since 1981 (Fig. 5). Since magnitude of river flow and fluctuations in river discharge between 1957 and 1981 did not greatly differ from the previous period of 1927 to 1957 (Fig. 4), it was the extensive implementation of flood protection structures along the river banks that was the most likely factor disrupting river-floodplain interactions, accelerating succession towards mature stages (Fig. 1). Although defences have been constructed along the Ebro River for centuries (Ollero, 2007), within the study reach almost all modern and effective flood protection structures were built between 1960 and 1980 (Ollero, 1992), and they are reinforced after every large flood.

\subsection{Natural ecotope succession}

Human alteration of river-floodplain interactions, which occurred sequentially, prevailed over the natural drivers of floodplain dynamics since 1957 . This promoted a different ecotope dynamics, as well as distinct initial conditions, for each time period considered in this study: (a) Channel Migration (1927-1957): unmodified flow regime and absence of flood protection, high conversion to anthropic landcovers took place at least since 1946, (b) Vertical Accretion (1957-1981): unmodified flow regime but establishment of flood protection (Ollero, 1992), high rates of conversion to anthropic landcovers and (c) Homogenization (1981-2003): modified flood regime and dyke construction, conversion to anthropic ecotopes with a great reduction in natural ecotopes.

During the first phase (1927-1957), the river-floodplain interactions during flow pulses not only stabilized part of the area occupied by initial and intermediate ecotopes, but also compromised the ongoing succession through main channel migration. Flood scouring forced larger patches of mature ecotopes to be located at the outer floodplain (Fig. 1), whereas flood events were sufficiently robust to rejuvenate mature patches located adjacent to the main channel (Fig. 6). Between 1946 and 1957, the elevated river-floodplain connectivity allowed for rapid readjustments to disturbances within the watershed, which explains the differences between initial and intermediate ecotope areas between 1946 and 1957 (Table 3).

During the second phase (1957-1981), river-floodplain interactions were strong enough to allow channel migration before the main channel adjusted to its "straitjacket" (sensu Lamers et al., 2006), and therefore, rejuvenation occurred at every successional stage (Fig. 6). The intense conversion to human-managed ecotopes restricted natural patches to the river corridor (Fig. 1), while lateral accretion was progressively constrained by dyke construction. As a consequence, succession was probably accelerated by higher vertical ac- cretion rates. Steiger et al. (2001) described this trend for a riparian area over a 30-y period in the Garonne river.

During the last period (1981-2003), the synergic effect of a modified flow regime and flood protection impeded ecotope rejuvenation, with the exception of in-channel ecotopes (Fig. 6). Between 1981 and 1998, the effect of non-erosive floods caused succession to proceed for the initial and intermediate ecotopes, resulting in the dominance of mature ecotopes at the end of the period (Table 3). The last examined transition period (1998-2003) revealed strong system stability (Fig. 6), despite the potential effects of a $3000 \mathrm{~m}^{3} / \mathrm{s}$ (60 y; 1981-2003) in February 2003. According to Amoros and Wade (1996), tremendous quantities of external energy are required to revert succession because in mature ecotopes succession is driven by autogenic processes. Indeed, only bank erosion at localized points was detected between 1998 and 2003.

\subsection{Restoration options for the study reach}

Prior to suggest feasible restoration guidelines, it is necessary to consider the current socio-economic context both at basin and reach scale. At basin scale, alternative strategies would need a more integrated use of natural resources, consisting primarily of soil and water (Comín, 1999). Beyond that, however, the current land uses within the Ebro Basin territory must also be integrated into a management plan, as performed for other threatened floodplains (Hale and Adams, 2007). At present, $80 \%$ of the Ebro water demand is diverted for agriculture and farming (Frutos, 2004), accounting for about $40 \%$ of the mean annual discharge. This trend is not likely to be changed because of further irrigation development is planned (www.chebro.es). At reach scale, public reclamation of agricultural lands for restoration purposes seems possible. The average age of landholders has increased through time, and a high percentage of the crops are only profitable due to agricultural subsidies. With regards to flood protection structures, decisions concerning on dyke reallocation rely entirely on the Ebro Basin administration.

Under this scenario, the more realistic option is to create a river corridor $(100-300 \mathrm{~m})$ in the study reach. Within this corridor, floodplain elements should tend to persist over time although their spatial distribution shifts, as pointed to occur in natural systems by Stanford et al. (2005). At the study reach this was observed until 1957, as shown by the proportion of natural ecotopes at different successional stages (Table 4). Peaks at the diversity spectra until 1957 (Fig. 5), before dykes started to be set, indicate that erosion during lowfrequency floods truncate successional pathways occurred at areas closed to the main channel. Consequently, the authors consider that the proportion of natural ecotopes either in 1957 or 1981 (Table 4) is a valid reference situation to be achieved within such dynamic corridor. Similarly, diversity spectra should peak within this corridor as observed prior to 1957 (Fig. 5) while successional pathways after restoration 
Table 4. Area (\%) covered by each natural ecotope for the array of natural landforms. Percentages are calculated for the area occupied by natural ecotopes (all less "anthropic"). Sub-totals by succesional stage (see Table 1) are also displayed.

\begin{tabular}{lrrrrrr}
\hline & 1927 & 1946 & 1957 & 1981 & 1998 & 2003 \\
\hline Main Channel & 16.3 & 17.4 & 19.9 & 28.0 & 19.8 & 20.2 \\
Gravel & 16.1 & 19.2 & 20.0 & 11.0 & 4.9 & 4.5 \\
Fines & 5.3 & 6.0 & 1.2 & 1.6 & 2.3 & 2.3 \\
Open Water & 1.0 & 3.1 & 2.4 & 4.3 & 2.6 & 2.8 \\
Young Island & 1.7 & 3.2 & 0.5 & 1.9 & 0.7 & 0.7 \\
\hline Initial & 40.3 & 48.8 & 43.9 & 46.8 & 30.3 & 30.3 \\
\hline Intermediate & 11.0 & 9.7 & 13.4 & 10.2 & 4.6 & 4.8 \\
Buried Trees & 12.5 & 5.8 & 7.8 & 5.1 & 1.1 & 1.3 \\
Macrophytes0 & 14.2 & 7.9 & 13.4 & 7.7 & 8.5 & 8.5 \\
Herbaceous & 0.1 & 0.2 & 2.1 & 0.8 & 2.0 & 1.9 \\
Inter. Island & 0.8 & 0.0 & 0.0 & 0.2 & 0.1 & 0.1 \\
\hline Intermediate & 38.5 & 23.5 & 36.7 & 24.1 & 16.3 & 16.7 \\
\hline Scattered Trees & 8.8 & 20.6 & 12.5 & 12.2 & 29.9 & 29.8 \\
Mature & 12.3 & 7.1 & 6.9 & 16.7 & 22.8 & 22.5 \\
Mature Island & 0.0 & 0.0 & 0.0 & 0.2 & 0.7 & 0.7 \\
\hline Mature & 21.2 & 27.7 & 19.4 & 29.1 & 53.4 & 53.0 \\
Total & 100.0 & 100.0 & 100.0 & 100.0 & 100.0 & 100.0 \\
\hline
\end{tabular}

should mimic those observed between 1927 and 1957 for natural ecotopes (Fig. 6).

To successfully restore the study reach towards this guiding image, previous research has to be implemented because current geomorphological and ecological processes are expected to differ from those at the beginning of the last century. The effect of modifying topography on the erosive capability of floods, and so over landscape dynamics, has to be first investigated by modelling surface flows. It allows predicting the effect of removing dykes or lowering floodplain heights at a specific area. Such actions would need an initial economic investment, which will be required to be periodic if the self-sustained dynamism is not reached within the dynamic corridor. This strategy has been proposed as a valid compromise between the need for flood protection and the growing demand for ecosystem rehabilitation in highly regulated rivers (Baptist et al., 2004). Similarly, the modification of different components of the flow regime has to be evaluated. Efforts should focus on evaluation the effect of restoring some components of the flow regime (frequency, duration, timing, rate of change) since that will more likely influence riparian vegetation growth and establishment (Poff et al., 1997; Bendix and Hupp, 2000; Hughes and Rood, 2003; Stromberg et al., 2007). Finally, the management of finegrained sediment dynamics is an urgent priority, as indicated by others (Owens et al., 2005; Rovira and Ibañez, 2007), if a more natural geomorphological functioning wants to be achieved. The delivery in the system of sediments belonging from lowering floodplain heights should be also evaluated as a restoration tool.

\section{Conclusions}

Flow regulation, human occupation and construction of flood protection structures have modified landscape structure and dynamics in the study reach. At present, the fluvial landscape is less diverse and dominated by mature stages and anthopic ecotopes, river-floodplain interactions are counteracted by dykes, and hydrological patterns are different, in terms of pulses of the river discharge, to those observed prior to river regulation (1927-1957). It seems, therefore, that a more natural functioning of the river-floodplain system should be achieved through ecological restoration. To accomplish this goal, ecotope diversity and dynamics observed between 1927 and 1957 is a valid reference situation. When implementing restoration, managers should consider the current hydrological and landscape constraints (dykes, vegetation encroachment, and raised surfaces) and the socio-economic context at basin and reach scale. The more realistic option is creating a dynamic river corridor whose extent should adapt to the restored flow regime. An initial economic inversion is necessary to reallocate dykes and lowering floodplain height; however, it might be required periodically if self-sustained restoration is not achieved within this dynamic river corridor.

Acknowledgements. The research was funded by the Department of the Environmental Science, Technology and University - Aragon government (Research group E-61 on Ecological Restoration) and MEC (CGL2005-07059). The Spanish Research Council (CSIC) granted Alvaro Cabezas through the I3P program (I3PEPD2003-2), which was financed by European Social Funds (UE). Thanks are extended to Alfredo Ollero for his collaboration with the flood protection data, and to Paz Errea and Jesus Martinez for their indispensable help with the GIS software.

Edited by: A. Butturini

\section{References}

Abaurrea, J., Asín, J., and Centellea, A.: Caracterización espaciotemporal de la evolución de la precipitación anual en la cuenca del Ebro, in: El agua y el Clima, edited by: Guijarro, J. A., Grimalt, M., Laita, M., and Alonso, S.:, Publicaciones de la Asociación Española de Climatología, 113-124, 2002.

Amoros, C. and Wade, P. M.: Ecological succesions, in: Fluvial Hydrosystems, edited by: Petts, G. E., and Amoros, C., Chapman \& Hall, London, 211-241, 1996.

Baptist, M. J., Penning, W. E., Duel, H., Smits, A. J. M., Geerling, G. W., van der Lee, G. E. M., and Van Alphen, J. S. L.: Assessment of the effects of cyclic floodplain rejuvenation on flood levels and biodiversity along the Rhine river, River Res. Appl., 20, 285-297, 2004.

Begueria, S.: Uncertainties in partial duration series modelling of extremes related to the choice of the threshold value, J. Hydrol., 303, 215-230, 2005.

Bendix, J. and Hupp, C. R.: Hydrological and geomorphological impacts on riparian plant communities, Hydrol. Process., 14, 2977-2990, 2000. 
Braun-Blanquet, J. and de Bolòs, O.: Las comunidades vegetales de la depresión del Ebro y su dinamismo, Delegación Medio Ambiente - Ayuntamiento de Zaragoza, Zaragoza, 278 pp., 1987.

Castro, P., Guerrero, J., and Muñoz, M. A.: Plan de Restauración del Bosque de Ribera en la Reserva Natural de los Galachos (Zaragoza), Investigacion, Consejo de Proteccion de la Naturaleza de Aragon, Zaragoza, 165 pp., 2001.

Comín, F. A.: Management of the Ebro River Basin: Past, present and future, Water Sci. Technol., 40, 161-168, 1999.

Cunnane, C.: A particular comparison of annual maxima and partial duration series methods of flood frequency prediction, J. Hydrol., 18, 257-271, 1973.

Dury, G. H.: Magnitude-Frequency analysis and Channel Morphology, in: Fluvial Geomorphology, edited by: Morisawa, M., Allen and Unwin, London, 91-121, 1981.

Forman, R. T. T. and Godron, M.: Landscape Ecology, John Wiley and Sons, New York, 1986.

Frutos, L. M., Ollero, A., and Sánchez Fabre, M.: Caracterización del Ebro y su cuenca y variaciones en su comportamiento hidrológico, in: Alteración de los regimenes fluviales peninsulares, edited by: Gil Oncina, A., Fundación Caja Murcia, Alicante, 223-280, 2004.

Geerling, G. W., Ragas, A. M. J., Leuven, R., van den Berg, J. H., Breedveld, M., Liefhebber, D., and Smits, A. J. M.: Succession and rejuvenation in floodplains along the river Allier (France), Hydrobiologia, 565, 71-86, 2006.

Hale, B. W. and Adams, M. S.: Ecosystem management and the conservation of river-floodplain systems, Landscape Urban Plan., 80, 23-33, 2007.

Hohensinner, S., Habersack, H., Jungwirth, M., and Zauner, G.: Reconstruction of the characteristics of a natural alluvial riverfloodplain system and hydromorphological changes following human modifications: The Danube River (1812-1991), River Res. Appl., 20, 25-41, 2004.

Hughes, F. M. R. and Rood, S. B.: Allocation of river flows for restoration of floodplain forest ecosystems: A review of approaches and their applicability in Europe, Environ. Manage., 32, 12-33, 2003.

Ibañez, C., Prat, N., and Canicio, A.: Changes in the hydrology and sediment transport produced by large dams on the lower Ebro river and its estuary, Regul. Rivers Res. Manag., 12, 51-62, 1996.

Jungwirth, M., Muhar, S., and Schmutz, S.: Re-establishing and assessing ecological integrity in riverine landscapes, Freshw. Biol., 47, 867-887, 2002.

Junk, W. J., Bayley, B., and Sparks, R. E.: The flood pulse concept in river-floodplain systems, in: Proc. Intern. Large River Symposium, Special Issue of J. Canad. Fish. Aquat. Sci., edited by: Dodge, D. P., 106, 11-27, 1989.

Kondolf, G. M.: Lessons learned from river restoration projects in California, Aquat. Conserv., 8, 39-52, 1998.

Lamers, L. P. M., Loeb, R., Antheunisse, A. M., Miletto, M., Lucassen, E. C. H. E. T., Boxman, A. W., Smolders, A. J. P., and Roelofs, J. G. M.: Biogeochemical constraints on the ecological rehabilitation of wetland vegetation in river floodplains, Hydrobiologia, 565, 165-186, 2006.

Lopez-Moreno, J. I., Begueria, S., and Garcia-Ruiz, J. M.: Influence of the Yesa reservoir on floods of the Aragon River, central Spanish Pyrenees, Hydrol. Earth. Syst. Sci., 6, 753-762, 2002.
Losada, J. A., Montesinos, S., Omedas, M., Garcia, M. A., and Galvan, R.: Cartografía de las inundaciones del Río Ebro en Febrero de 2003: Trabajos de Fotointerpretación, teledetección y analisis SIG en el GIS-EBRO, Metods Cuantitativos, SIG y Teledeteccion., Murcia, 207-218, 2004.

Miller, J. R., Schulz, T. T., Hobbs, N. T., Wilson, K. R., Schrupp, D. L., and Baker, W. L.: Changes in landscape structure of a southestearn Wyoming riparian zone following shifts in stream dynamics, Biol. Conserv., 72, 371-379, 1995.

McGarigal, K. and Marks, B.: FRAGSTATS: Spatial Analysis Program for Quantifiying Landscape Structure, USDA For. Serv. Gen. Tech. Rep. PNW-351., 1995.

Ollero, A.: Los meandros libres del Ebro medio (Logroño-La Zaida): geomorfología fluvial, ecogeografía y riesgos., Dep. Geografía y Ordenación del Territorio, Universidad de Zaragoza, Zaragoza, 1992.

Ollero, A.: Dinámica reciente del cauce de el Ebro en la Reserva Natural de los Galachos, Rev. C. \& G., 9, 85-93, 1995.

Ollero, A.: Channel adjustments, floodplain changes and riparian ecosystems of the middle Ebro River: Assessment and management, Int. J. Water Resour. D., 23, 73-90, 2007.

Owens, P. N., Batalla, R. J., Collins, A. J., Gomez, B., Hicks, D. M., Horowitz, A. J., Kondolf, G. M., Marden, M., Page, M. J., Peacock, D. H., Petticrew, E. L., Salomons, W., and Trustrum, N. A.: Fine-grained sediment in river systems: Environmental significance and management issues, River Res. Appl., 21, 693717, 2005

Pinilla, V.: The development of irrigated agriculture in twentiethcentury Spain: a case study of the Ebro basin, Agr. Hist. Rev., 54, 122-141, 2006.

Poff, N. L., Allan, J. D., Bain, M. B., Karr, J. R., Prestegaard, K. L., Richter, B. D., Sparks, R. E., and Stromberg, J. C.: The natural flow regime, Bioscience, 47, 769-784, 1997.

Rohde, S., Hostmann, M., Peter A., and Ewald, K. C.: Room for rivers: An integretive search strategy for floodplain restoration, Landscape Urban Plan. 78, 50-70, 2006.

Regato, P.: Contribucion al estudio de la flora y la vegetación del galacho de la Alfranca en relación con la evolución del sistema fluvial, Naturaleza en Aragon, Diputación General de Aragon, Zaragoza, 189 pp., 1988.

Rovira, A. and Ibañez, C.: Sediment Management Options for the lower Ebro River and its Delta, J. Soils Sediments, 7, 285-295, 2007.

Stanford, J. A., Lorang, M. S., and Hauer, F. R.: The shifting habitat mosaic of river ecosystems, Ver. Int. Verein. Limnol., 29, 123136, 2005.

Steiger, J., Gurnell, A. M., Ergenzinger, P., and Snelder, D.: Sedimentation in the riparian zone of an incising river, Earth Surf. Proc. Land., 26, 91-108, 2001.

Stromberg, J. C., Beauchamp, V. B., Dixon, M. D., Lite, S. J., and Paradzick, C.: Importance of low-flow and high-flow characteristics to restoration of riparian vegetation along rivers in and southwestern United States, Freshwater Biol., 52, 651-679, 2007.

Tockner, K., Malard, F., and Ward, J. V.: An extension of the flood pulse concept, Hydrol. Process., 14, 2861-2883, 2000.

Tockner, K. and Stanford, J. A.: Riverine flood plains: present state and future trends, Environ. Conserv., 29, 308-330, 2002. 
Ward, J. V. and Stanford, J. A.: Ecological Connectivity in Alluvial River Ecosystems and Its Disruption by Flow Regulation, Regul. Rivers Res. Manage., 11, 105-119, 1995.

Ward, J. V., Malard, F., and Tockner, K.: Landscape ecology: a framework for integrating pattern and process in river corridors, Landscape Ecol., 17, 35-45, 2002.
Whited, D. C., Lorang, M. S., Harner, M. J., Hauer, F. R., Kimball, J. S., and Stanford, J. A.: Climate, hydrologic disturbance, and succession: Drivers of floodplain pattern, Ecology, 88, 940-953, 2007. 